\title{
A Rare Cause of Multiple Pulmonary Nodules: Computed Tomography Features of Benign Metastasizing Leiomyoma
}

\author{
๑ Serdar Aslan, ${ }^{\oplus}$ Muzaffer Elmalı²
}

\author{
'Department of Radiology, Turhal \\ State Hospital, Tokat, Turkey \\ 2Department of Radiology, \\ Ondokuz Mayıs University Faculty \\ of Medicine,Samsun, Turkey \\ Submitted: 27.10 .2018 \\ Accepted: 19.12.2018 \\ Correspondence: Serdar Aslan, \\ Turhal Devlet Hastanesi, Radyoloji \\ Kliniği, Turhal, 60300 Tokat, Turkey \\ E-mail: serdaraslan28@hotmail.com

Keywords: Benign
metastasizing leiomyoma;
chest computed tomography;
uterine myomatosis.

\begin{abstract}
Benign metastasizing leiomyoma (BML) defines metastatic foci containing the myometrial smooth muscle. It is most commonly found in the lungs and is among the rare causes of multiple pulmonary nodules. Pulmonary BML (PBML) is often asymptomatic and is detected incidentally on chest radiographs taken for other reasons. PBML has been reported to be associated with uterine myomatosis. In this case report, we aimed to present chest computed tomography findings of asymptomatic PBML in a case of hysterectomy performed due to myomatosis 3 years ago.
\end{abstract}

\section{INTRODUCTION}

Benign metastasizing leiomyoma (BML) defines metastatic foci containing the myometrial smooth muscle. It is very rare, and only 100 cases have been reported in the literature so $\mathrm{far}^{\left[{ }^{[1]}\right.}$ Due to the low number of cases, the incidence, pathogenesis, and treatment remain uncertain. It is most commonly found in the lungs, among the rare causes of multiple pulmonary nodules. Pulmonary BML (PBML) is often asymptomatic and is detected incidentally on chest radiographs taken for other reasons. Rarely, non-specific symptoms, such as coughing or shortness of breath, may occur. ${ }^{[2]}$ We aimed to present chest computed tomography (CT) findings of asymptomatic PBML in a case of hysterectomy performed due to uterine myomatosis 3 years ago.

\section{CASE REPORT}

A 48-year-old woman (gravida 3, para 3) was referred to our outpatient chest diseases clinic so the lesions detected in a chest X-ray taken at the external center due to trauma could be evaluated. No abnormality was detected during the physical examination or in the laboratory values. In her medical history, she had a hysterectomy
3 years ago due to uterine myomatosis. A chest $\mathrm{CT}$ was performed to evaluate the lesions detected on chest $X$ ray. On the chest CT images, multiple solid masses were found in both lung parenchyma, the largest mass of which was located paramediastinally in the left upper lobe of the lung (Fig. Ia, b). A CT-guided needle biopsy was performed to identify the masses detected. BML was the pathological diagnosis (Fig. 2). Additional immunohistochemical analysis found desmin, muscle-specific actin and vimentin, and estrogen and progestin receptors positive (Fig. 3a, b). Hormonotherapy (aromatase inhibitor) was initiated due to multiple lesions, an asymptomatic case, and positive hormone receptors. Follow-up examinations and mass scanning were decided according to the fact that they will give response hormonotherapy. Written informed consent was obtained from the patient to publish this case.

\section{DISCUSSION}

In this case report, we presented chest CT findings in a patient with PBML who had previously undergone hysterectomy due to uterine myomatosis. Uterine leiomyoma is the most common gynecologic neoplasm in women of reproductive age and is caused by the clonal proliferation 

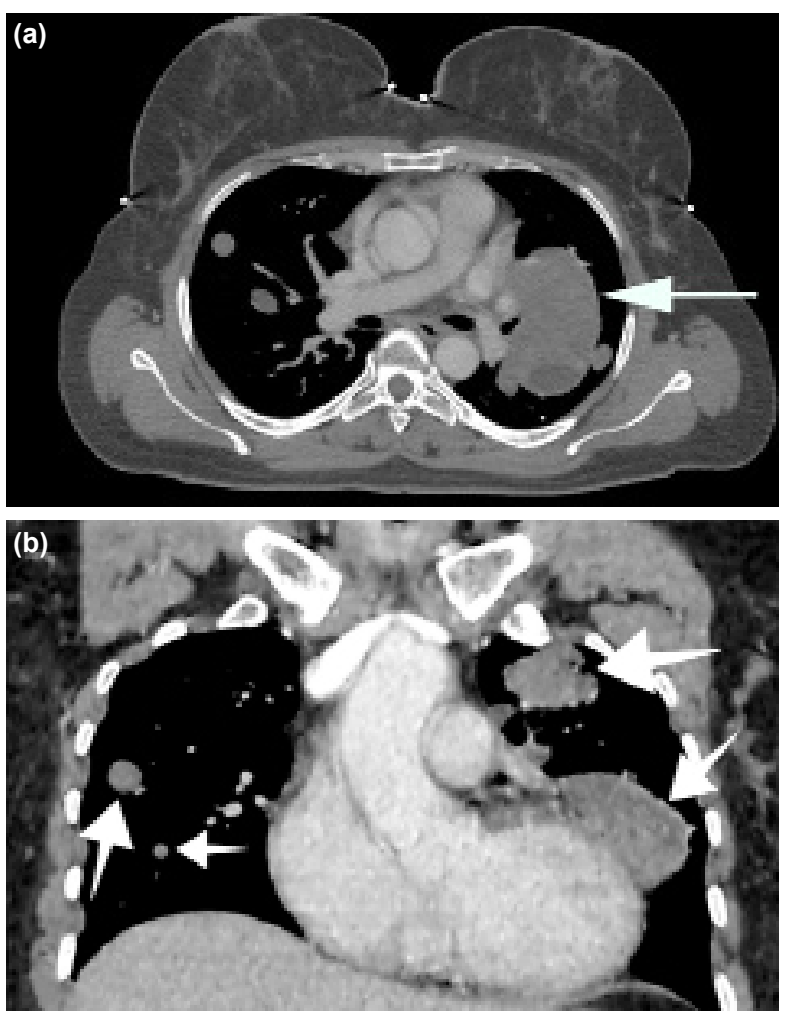

Figure 1. (a) On the axial contrast-enhanced CT, images show a mass $9 \times 5 \mathrm{~cm}$ in size in the left upper lobe of the lung (arrow), non-enhanced after a CM injection, and a cystic region in the posterior section. (b) On the coronal contrast-enhanced CT, images show non-enhanced masses after a CM injection in both the lungs (arrows), except for the defined mass.

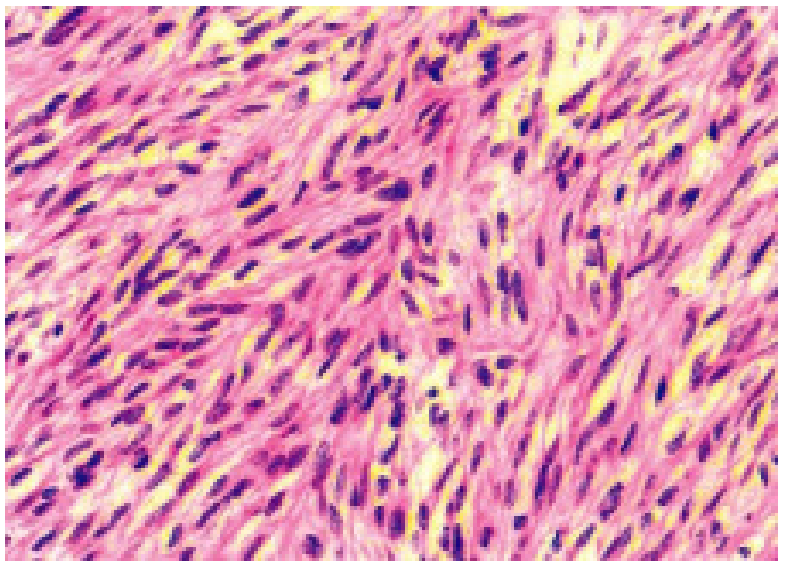

Figure 2. Paramediastinal lung nodule having spindle cell lesions of similar morphology, as seen in the uterus (smooth muscle fibers with cigar-shaped nuclei) (Hematoxylin and Eosin, $\mathrm{x} 200)$.

of the myometrial smooth muscle tissue. BML is caused by the uterine leiomyoma metastasis. BML is most commonly seen in the lung, but it may occur in many different locations, including the paraaortic lymph nodes, abdominal lymph nodes, heart, breast, liver, and esophagus. ${ }^{[3]}$ The PBML pathogenesis has not yet been fully explained. However, various pathogenetic mechanisms such as the in situ proliferation of hormone-sensitive smooth muscle bun-

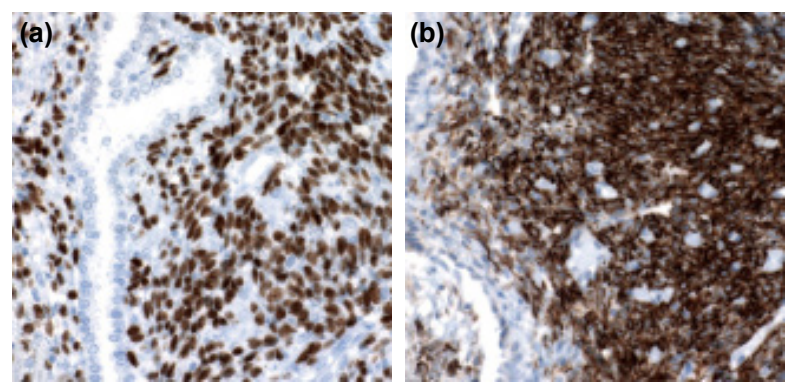

Figure 3. (a) PBML showing a strong nuclear positivity for estrogen receptors (b) and desmin.

dles, benign smooth muscle cells that are hematogenously transported from the uterine leiomyoma and colonized in the lung, and low-grade uterine leiomyosarcoma that metastasized to the lung have been suggested. ${ }^{[4]}$ Furthermore, there are suggestions that the PBML development is due to the hematogenous transport induced by uterine leiomyoma surgery because PBML often develops after a surgical procedure involving uterine leiomyoma, but rarely after a cesarean section. ${ }^{[4,5]}$

Radiologically, PBML can occur as well-defined nodules, ranging from a few millimeters to several centimeters in diameter, which can be solitary or multiple. ${ }^{[6]} A$ contrast material (CM) injection does not show any post-contrast enhancement. Endobronchial and pleural preservation is a characteristic of PBML. In rare cases, cystic lesions with the milier pattern, cavitary lung nodules, and multiloculated fluid have been reported. ${ }^{[2,7]}$ In our case, masses different in sizes, which did not show an enhancement after $\mathrm{CM}$, some of them including cystic areas, were observed.

Pathologically, PBML is benign. The formation of cytologic atypia, coagulable tumor cell necrosis, increased mitosis (more than 5 at a 10X magnification), the absence of high cellularity, and the low $\mathrm{Ki}-67$ index support the low proliferative state and benign nature of these tumors. A histological examination reveals smooth muscle cells without anaplasia or vascular invasion. Various immunohistochemical markers such as desmin, muscle-specific actin, and vimentin confirm that these tumors are derived from the mesenchymal derivative and are caused by smooth muscle differentiation. The positive presence of estrogen and progesterone receptors also supports that PBML originates in the female genital tract. ${ }^{[8]}$

No standard management has been established due to the low number of cases for the PBML treatment. Due to the fact that PBML is hormone sensitive, treatment is based on medical oophorectomy or surgery with hormonal manipulation. A spontaneous PBML regression has been reported due to changes in pregnancy, postnatal period, and the hormonal environment in menopause. ${ }^{[9]}$ Hormone treatments such as tamoxifen (a selective estrogen receptor modulator) and aromatase inhibitors have been shown to help reduce the tumor size. Medical oophorectomy with gonadotropin-releasing hormone agonists that suppress the endogenous gonadotropin secretion required for the gonadal steroid production has been described with good 
outcomes in various reports. ${ }^{[9,10]}$ Hysterectomy has shown that removing the primary metastasis source does not reduce the tumor size. ${ }^{[I]}$ In addition, pulmonary nodules were also described after hysterectomy. ${ }^{[6]}$ Another point of view in this regard is the surgical removal of metastases where possible. ${ }^{[1,3]}$ We found multiple lung metastases in our case, despite hysterectomy. We started aromatase treatment primarily because of multiple metastases, an asymptomatic case, and positive estrogen and progesterone receptors found after the biopsy.

\section{CONCLUSION}

PBML is a rare condition that is most often coincidentally detected during imaging in cases of uterine leiomyoma. It is thought that its spreading is hematogenous. Since PMBL varies between clinical cases, and no standard treatment has been identified, it is very important to have an individualized approach to treatment. Imaging modalities and image-guided biopsy play an important role in determining the individual approach.

\section{Informed Consent}

Written informed consent was obtained from the patient for the publication of the case report and the accompanying images.

Peer-review

Internally peer-reviewed.

Authorship Contributions

Concept: S.A., M.E.; Design: S.A.; Data collection \&/or processing: S.A., M.E.; Analysis and/or interpretation: S.A., M.E.; Literature search: S.A., M.E.; Writing: S.A.; Critical review: M.E.
Conflict of Interest

None declared.

\section{REFERENCES}

1. Rege AS, Snyder JA, Scott WJ. Benign metastasizing leiomyoma: a rare cause of multiple pulmonary nodules. Ann Thorac Surg 2012;93:e149-51. [CrossRef]

2. Goyle KK, Moore DF, Garett C, Goyle V. Benign metastasizing leiomyomatosis: case report and review. Am J Clin Oncol 2003;26:473-6. [CrossRef]

3. Kwon YI, Kim TH, Sohn JW, Yoon HJ, Shin DH, Park SS. Benign pulmonary metastasizing leiomyomatosis case report and a review of the literature. Korean J Intern Med 2006;21:173-7. [CrossRef]

4. Patton KT, Cheng L, Papavero V, Blum MG, Yeldandi AV, Adley BP, et al. Benign metastasizing leiomyoma: clonality, telomere length and clinicopathologic analysis. Mod Pathol 2006;19:130-40. [CrossRef]

5. Nardo LG, Iyer L, Reginald PW. Benign pulmonary metastasizing leiomyomatosis in pregnancy: a rare complication after cesarean section. Acta Obstet Gynecol Scand 2003;82:770-2. [CrossRef]

6. Chen S, Zhang Y, Zhang J, Hu H, Cheng Y, Zhou J, et al. Pulmonary benign metastasizing leiomyoma from uterine leiomyoma. World J Surg Oncol 2013;11:163. [CrossRef]

7. Lipton JH, Fong TC, Burgess KR. Miliary pattern as presentation of leiomyomatosis of the lung. Chest 1987;91:781-2. [CrossRef]

8. Rao UN, Finkelstein SD, Jones MW. Comparative immunohistochemical and molecular analysis of uterine and extrauterine leiomyosarcomas. Mod Pathol 1999;12:1001-9.

9. Rivera JA, Christopoulos S, Small D, Trifiro M. Hormonal manipulation of benign metastasizing leiomyomas: report of two cases and review of the literature. J Clin Endocrinol Metab 2004;89:3183-8.

10. Maruo T, Ohara N, Wang J, Matsuo H. Sex steroidal regulation of uterine leiomyoma growth and apoptosis. Hum Reprod Update 2004;10:207-20. [CrossRef]

\section{Çoklu Pulmoner Nodüllerin Nadir Bir Nedeni: Benign Metastaz Yapan Leiomyomun Bilgisayarlı Tomografi Özellikleri}

Benign metastaz yapan leiomiyoma (BML), miyometriyal düz kas içeren metastatik odakları tanımlar. En sık akciğerlerde görülür ve multipl pulmoner nodüllerin nadir nedenleri arasındadır. Pulmoner BML (PBML) sıklıkla semptomsuzdur ve başka nedenlerle yapılan çekilen gögüs grafilerinde tesadüfen saptanır. Uterus miyomatozis ile ilişkili olduğu bildirilmektedir. Biz bu olgu sunumumuzda üç yıl önce miyomatozis nedeniyle histerektomi yapılan semptomsuz PBML olgusunun toraks bilgisayarlı tomografi bulgularını sunmayı amaçladık.

Anahtar Sözcükler: Benign metastaz yapan leiomyoma; toraks bilgisayarlı tomografisi; uterin myomatozis. 